\title{
Improvement of Nutrition Production by Protoplast Fusion Techniques in Chlorella vulgaris
}

\section{Kusumaningrum $\mathbf{H P}^{1 *}$ and Zainuri $\mathbf{M}^{2}$}

${ }^{1}$ Laboratory of Genetics, Faculty of Science and Mathematics, Department of Biology, Diponegoro University, SH Tembalang, Semarang, Indonesia ${ }^{2}$ Marine Laboratory, Faculty of Fisheries and Marine Science, Diponegoro University, SH Tembalang, Semarang, Indonesia

\begin{abstract}
Recent decades showing remarkable development of the biotechnology of microalgae. Valuable product for food, nutrition and other applications will extend into broader area. Natural nutrition production from microalgae are not yet competitive with their synthetic levels. Chlorella is widely used as a health food and feed supplement, as well as in the pharmaceutical and cosmetics industries. Protoplast fusion was found to be an efficient method in improving its nutrition production and diversification in Chlorella vulgaris. The research was carried out by application of protoplast fusion on interspecific microalgae of $C$. vulgaris. The fusant was subjected for analysis of nutrition content by GCMS methods on C. vulgaris powder from $100 \mathrm{~L}$ liquid cultivation of fusant. The research result gained fusant in high mass production level. Nutrition analysis of fusants showed 17 amino acid with high concentration glutamic acid (14495.52 ppm) followed by leucine (10856.97 ppm) and Aspartic acid (10378 ppm). Palmitic acid $(1.59 \%)$ was showed highest concentration in its lipid acid profile. Lipid analysis also showed polyunsaturated fatty acids (PUFA) with concentration $1.0987 \%$ and DHA $0.2 \%$. Surprisingly, the fusant also revealed Omega 9 instead of Omega 3 and Omega 6. The research result showed potential acquisition of improvement nutrition by protoplast fusian application on microalgae.
\end{abstract}

Keywords: Microalgae; Nutrition; Chlorella; Protoplast fusion

\section{Introduction}

Microalgae represent the largest natural nutrition in the aquatic food chain of animal aquaculture. C. vulgaris was one of the source of aquatic nutrition [1]. This species have been exploited for aquaculture feeds as therapeutic or nutritional supplements [2]. Production of genetically improved strain by somatic fusion and hybridization on algae has been reported in some algae [3]. Protoplast fusion has been conducted inter and intraspecies on several genus of microalgae [4]. However, microalgae are still not a well-studied group from a biotechnological point of view. The genetic improvement of algal strains is also a present challenge to improve the potency of microalgae. Algal production systems need to be further improved to become more competitive and more economically feasible.

Protoplast fusion was in vitro genetic manipulation techniques which are more effective compared with conventional techniques used for strain improvement like mutation and selection [5-9]. Somatic hybridization allowed by this technique has been proven effective increasing nutrition and valuable metabolites production [10]. Combination of fully or partially nuclear and cytoplasmic genomes levels also enables to performed using protoplast fusion. Microalgae are very rich in nutrition. Indeed, some nutrition are of major importance for many marine animals for the growth and metamorphosis of many larvae [7-15]. Application of protoplast fusion process for microalgae Chlorella had conducted to improve their carotenoid for animal aquatic supplement [10]. The use of fusant as a natural feed supplement is potential to overcome synthetic feed [1,16-19]. Application of fusant as natural feed supplement on Penaeus monodon post larvae had raised the weight growth, and survival from microbial diseases and immune response in wide range of salinity $[1,20]$.

Protoplast fusion on algae algae have been reported as a valuable process to improve their nutrition. However, there are inconclusive reports about their effect of nutrition value of microalgae algae and the bioavailability of the nutrition within. More research is needed to investigate the effect of protoplast fusion for the nutrititonal value in $C$. vulgaris in vivo. The purpose of this study is to improve the of nutrition production on C. vulgaris using protoplast fusion techniques.

\section{Materials and Methods \\ Chlorella vulgaris cultivation}

The C. vulgaris was the microalgae originally from Brackish Water Aquaculture Development Centre (BBPBAP) on Jepara, Indonesia. They were grown in seawater tanks with the room temperature, recirculated and aerated in salinity at $25 \%$ to $30 \%$. The microalgae were cultivated using sea water enriched with Walne media.

\section{Microalgae media}

Walne media for microalgae growth and cultivation consists of $\mathrm{FeCl}_{3} 0.15 \mathrm{gL}^{-1}, \mathrm{NaNO}_{3} 10 \mathrm{gL}^{-1}, \mathrm{Na}_{2}$ EDTA $45 \mathrm{mgL}^{-1}, \mathrm{NaH}_{2} \mathrm{PO}_{4} 20 \mathrm{gL}^{-1}$, $\mathrm{H}_{3} \mathrm{BO}_{3} 3.36 \mathrm{gL}^{-1}, \mathrm{MnCl}_{2} .4 \mathrm{H}_{2} \mathrm{O} 0.36 \mathrm{gL}^{-1}$, trace metal solution $1 \mathrm{mLL}^{-1}$, and distilled water. Trace metal solution consists of $\mathrm{ZnSO}_{4} .7 \mathrm{H}_{2} \mathrm{O} 0.222$ $\mathrm{gL}^{-1} ; \mathrm{NaMoO}_{4} .5 \mathrm{H}_{2} \mathrm{O} 0.39 \mathrm{gL}^{-1} ; \mathrm{Co}\left(\mathrm{NO}_{3}\right)_{2} \cdot 6 \mathrm{H}_{2} \mathrm{O} 0.0494 \mathrm{gL}^{-1} ; \mathrm{H}_{3} \mathrm{BO}_{3} 2.86$ $\mathrm{gL}^{-1}$; $\mathrm{CuSO}_{4} .5 \mathrm{H}_{2} \mathrm{O} 0.079 \mathrm{gL}^{-1}$; and $\mathrm{MnCl}_{2} .4 \mathrm{H}_{2} \mathrm{O} 1.81 \mathrm{gL}^{1} ; \mathrm{pH} 6.8$. The ingredients were dissolved in $200 \mathrm{~mL}$ of distilled water. The solution was adjusting the $\mathrm{pH}$ to 7.6 with $\mathrm{HCl}$ or $\mathrm{NaOH}$ while boiled for 10 min continued with filtering and brought to $1 \mathrm{~L}$ by distilled water. Sterilization was done using autoclave at $15{\mathrm{lb} \cdot \mathrm{in}^{-2}}^{-103 \mathrm{kPa} \text { and }}$ $120^{\circ} \mathrm{C}$ ). The medium was used by adding $10 \mathrm{~mL}$ solution to each $1 \mathrm{~L}$ of seawater $[21,22]$.

\section{Nutrition analysis}

Nutrition analysis was conducted at Diponegoro University

*Corresponding author: Kusumaningrum HP, Laboratory of Genetics, Biology Department, Faculty of Science and Mathematics, Diponegoro University, SH Tembalang, Semarang-50275, Indonesia, Tel: +62-024-76480923, Fax: +62-02476480923; E-mail: herminsakti@gmail.com

Received December 11, 2017; Accepted December 29, 2017; Published January 05, 2018

Citation: Kusumaningrum HP, Zainuri M (2018) Improvement of Nutrition Production by Protoplast Fusion Techniques in Chlorella vulgaris. J Food Process Technol 9: 711. doi: 10.4172/2157-7110.1000711

Copyright: () 2018 Kusumaningrum HP, et al. This is an open-access article distributed under the terms of the Creative Commons Attribution License, which permits unrestricted use, distribution, and reproduction in any medium, provided the original author and source are credited. 
using GCMS method using. Gravimetry method was used to analyze moisture, ash, fiber crude and lipid. Macro-Kjeldhal method was used to determine protein. Analyzing of fatty acid and amino acid profile were conducted at PT. Saraswanti Indo Genetech, Bogor based on AOAC method [23]. Amino acids were determined by UPLC Method and fatty acids were determined by GC Method. Carbohydrates were analyzed utilizing a colorimetric technique.

\section{GC-MS analysis}

A gas chromatography-mass spectroscopy (GC-MS) technique was used to analyze the chemical composition of microalgae. The sample was mixed with $300 \mu \mathrm{ln}$-hexanePatchouli oil were separated on a $30 \mathrm{~m}$ $\times 0.25 \mathrm{~mm}(\mathrm{l} \times$ i.d. $)$ capillary column coated with a $0.25 \mathrm{~mm}$ film of $5 \%$ phenyl methyl siloxane at a column temperature of $80^{\circ} \mathrm{C}$ for injection. Temperature programming started at $10^{\circ} \mathrm{C} \mathrm{min}^{-1}$ to $150^{\circ} \mathrm{C}$ and then from $5^{\circ} \mathrm{C} \mathrm{min}{ }^{-1}$ to $250^{\circ} \mathrm{C}$ and finally from $10^{\circ} \mathrm{C} \mathrm{min}^{-1}$ to $280^{\circ} \mathrm{C}$ and held for $5 \mathrm{~min}$. Using splitless injection, $(2 \mu \mathrm{L})$, helium was employed as the carrier gas with a flow rate of $1 \mathrm{~mL} / \mathrm{min}$. The spectrometer was operated in electron-impact (EI) mode, with electron energy of $70 \mathrm{eV}$ and a scan range of 50- $550 \mathrm{amu}$. The inlet and ionization source temperatures were $240^{\circ} \mathrm{C}$ and $280^{\circ} \mathrm{C}$, respectively.

\section{Protoplast fusion}

Fusion of protoplast was conducted using modified methods of Tjahyono et al. [24] and Uppalati and Fujita [25]. Cells of microalgae with a density of $10^{7}$ was soaked in a solution of sodium succinate buffer ( $\mathrm{pH} 4.5$ ), consist of $0.7 \mathrm{M}\left(\mathrm{NH}_{4}\right)_{2} \mathrm{SO}_{4}, 0.6 \mathrm{M} \mathrm{KCl}$ and $0.1 \mathrm{M}$ 2 -mercaptoethanol. The protoplast is obtained by suspending the microalgae cells into 2-3 mg mL $\mathrm{m}^{-1}$ lysozyme for 2-3 hours. Early growth phase of protoplast (approx.107-10 cells $\mathrm{mL}^{-1}$ ) were washed with osmotic solubilizing solution (potassium phosphate buffer) followed by its suspension in $3 \%$ sodium chloride buffer, $1 \mathrm{mM} \mathrm{CaCl}_{2}$ and $0.1 \mathrm{M}$ 2-mercaptoethanol. The protoplast was resuspended in $1 \% 10 \mathrm{mg} \mathrm{mL}^{-1}$ of lysozyme on $35^{\circ} \mathrm{C}$ for 20 minutes. The protoplast of Chlorella was kept in Walne medium for $45 \mathrm{~min}$. Composition of Walne medium was sea water, $60 \mathrm{mM}$ polyethylene glycol (Mr.6000; Sigma), $5 \mathrm{mM}$ glycine and $10 \mathrm{mM} \mathrm{CaCl}_{2}$. The process was followed by serial washing in suspension containing $5 \mathrm{mM}$ glycine and $10 \mathrm{mM} \mathrm{CaCl}_{2}$. Protoplast regeneration were made by growing the recombinant on Walne medium using sea water containing $5 \mathrm{mM}$ glycine and $10 \mathrm{mM} \mathrm{CaCl}_{2}$ and incubated for 5-7 days [26,27].

\section{Results and Discussion}

\section{Protoplast fusion on C. vulgaris}

Microalgae $C$. vulgaris has been already characerized using moleculer techniques before protoplast fusion process [28]. The protoplat fusion process had produced stable hybrids which in tend to combine more than one cell and create new cell wall as illustrated in Figure 1. We can also see that the combination of more than one cell will make the cell have a smaller size than its parent.

The Chlorella fusant are shown in Figure 1. The protoplast fusion result showed variation of cell combination. Each fusant consist of two or more cell that combine in one cell. These fusant were grown in salinity about $15 \%$. Growth were analyzed for the fusant and were compared with the parental $C$. vulgaris. The growth rate analysis revealed significant differences between fusant and parental. The growth of $C$. vulgaris and fusant during cultivation share the same pattern for eight day. This pattern are in accordance with Chia et al. [26]. The observed growth phases consist of the lag phase, the exponential phase and the

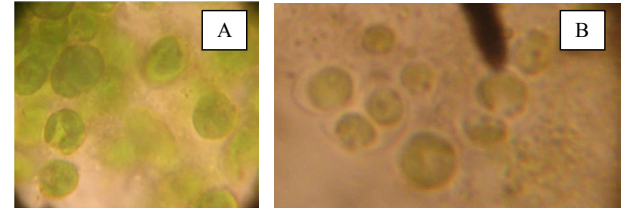

Figure 1: Protoplast fusion product (A: Parental C. Vulgaris; B: Fusant).

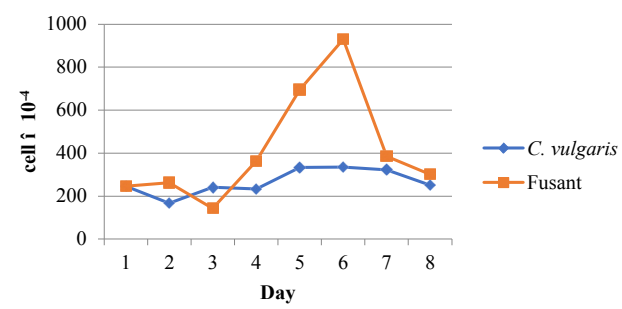

Figure 2: Growth of parental C. vulgaris and fusant.

\begin{tabular}{|c|c|c|c|c|}
\hline No & Parameters & C.vulgaris & Fusant & Unit \\
\hline 1 & Total energy & 154.43 & 179.24 & k-kal/100 g \\
\hline 2 & Lipid energy & 41.85 & $55 . .80$ & k-kal/100 g \\
\hline 3 & Water & 11.22 & 12.29 & $\%$ \\
\hline 4 & Ash & 57.99 & 50.65 & $\%$ \\
\hline 5 & Total lipid & 4.65 & 6.20 & $\%$ \\
\hline 6 & Protein & 10.36 & 13.82 & $\%$ \\
\hline 7 & Total carbohydrate & 15.78 & 17.04 & $\%$ \\
\hline
\end{tabular}

Table 1: Proximate analysis of Chlorella vulgaris and fusant.

stationary phase. Both parental and fusant need adaptation on their growth which is marked with the reduction of cell count (Figure 2). The fusant showed faster growth comparing with the parental especially in the day sixth. The expermented microalage alo showed shorter growth comparing with study by Costard et al. [27] which is needed 12 days for Chlorella sp. growth.

\section{Proximate analysis}

Microalgae can be considered into organisms that producing a distinct range of chemical and biological compounds, principally vitamins, pigments, proteins, minerals, lipids and polysaccharides. The high nutrition content of microalgal species is one of the main reasons to consider them as an important source of nutrition for multipurpose target. This proximate composition of C. vulgaris and fusants are summarized in Table 1. Almost all of the proximate content of the fusant microalgae species tend bigger that their parent ranging from $15 \%$ to $25 \%$. This result was in agreement with Gupta et al. [29] for the hybrid fom protoplast fusion between macroalgae Monostroma oxyspermum (Kutz.) Doty and Ulva reticulata Forsskål.

In this research, microalga cell harvesting was conducted in stationary phase to complete the process of adaptation and regeneration. The reduced growth seems affected the nutrition on microalgal cell exhibited by a low protein and higher carbohydrate content. These factor were determined in the study of Sharma et al. [30] which showed that lower degree of illumination will favors higher protein in Chlorella. C. vulgaris and fusant exhibited $5 \%$ to $6 \%$ total lipid content. $\mathrm{Bi}$ and $\mathrm{He}$ [31] reported that C. vulgaris has total lipid content varied from $30 \%$ to $60 \%$ depend on nutritional and growth conditions. However, the lipid content in this research was higher comparing with the study on $C$. vulgaris by Yusof et al. [32], and Torres et al. [33]. 


\section{Protein content of $C$. vulgaris and fusant}

Information on the protein value microalgae will provide their essential roles and development by application of protein supplement because protein content is a major factor determining the nutritional value of microalgae. The cells of $C$. vulgaris and fusant are capable of synthesizing almost all amino acids. Typical amino acid analysis of experimented microalgae is shown in Table 2. The presence of essential amino acids (ESA) such as arginine, phenylalanine, histidine, isoleucine, leucine, lysine, methionine, threonine, and valine was found in the profile of C. vulgaris and fusant, except. This result is almost the same with study by Samek et al. [34] which is found seven essential amino acid on Chlorella, while Safafar et al. [35] found all the amino acid. This research was not found tryptophan in the amino acid profile on both experimented microalgae. This result was confirmed by Volkman et al. [36], Bleakley and Hayes [15] which states that tryptophan and lysine are often limiting amino acids in most algae species.

Although Aspartic acid and Glutamic acid were non-essential amino acids (NESA) but they constitute the highest proportion of of the total amino acids among parental microalgae and fusant. This result was supported by Samek et al. [34], Bleakley and Hayes [15]. The result also showed some differences in ESA and NESA concentration with other microalgae like Samek et al. [34]. Cysteine have the lowest level of NESA in the investigated microalgae and fusant, as also typically occurs in many seaweed species [15]. However, experiment on Spirulina platensis, Chlorella sp, C. kessleri, and S. quadricauda showed that histidin having low level NESA [34]. However, total protein contents were directly proportionate to the growth and chlorophyll contents. The highest amount of protein was found in natural day light at $25^{\circ}$ to $30^{\circ}$ as also performed in this research.

\section{The fatty acid profile of Chlorella vulgaris and fusant}

Algal lipids are composed of glycerol, sugars or bases esterified to saturated or unsaturated fatty acids (12 to 22 carbon atoms). The results presented in Table 3 showed that $C$. vulgaris and fusant contain the Polyunsaturated Fatty Acids (PUFAs) include docosahexaenoic acid (DHA), eicosapentaenoic acid (EPA), arachidonic acid (AA), $\gamma$-linolenic acid (GLA), alpha linolenic acid ( ALA) which have been widely recognized as beneficial towards human health. These results are similar to those observed by Yusof et al. [32]. This result was in

\begin{tabular}{|c|c|c|c|c|}
\hline S. no & Essential amino acids & C. vulgaris & Fusant & ppm \\
\hline 1 & Leucine & 8142.73 & 10856.97 & $\mathrm{ppm}$ \\
\hline 2 & Threonine & 6113.47 & 8151.29 & $\mathrm{ppm}$ \\
\hline 3 & Lysine & 5481.07 & 7308.09 & $\mathrm{ppm}$ \\
\hline 4 & Valine & 5052.74 & 6736.99 & $\mathrm{ppm}$ \\
\hline 5 & Phenylalanin & 4701.26 & 6268.34 & $\mathrm{ppm}$ \\
\hline 6 & Isoleucine & 4049.33 & 5399.10 & $\mathrm{ppm}$ \\
\hline 7 & Methionine & 1647.96 & 2197.28 & $\mathrm{ppm}$ \\
\hline 8 & Arginine & 5071.65 & 6762.20 & $\mathrm{ppm}$ \\
\hline 9 & Histidine & 1386.05 & 1848.07 & $\mathrm{ppm}$ \\
\hline S. no & Non-essential amino acids & $\mathbf{C .}$ vulgaris & Fusant & $\mathrm{ppm}$ \\
\hline 1 & Glutamic acid & 10871.64 & 14495.52 & $\mathrm{ppm}$ \\
\hline 2 & Aspartic acid & 7783.52 & 10378.02 & $\mathrm{ppm}$ \\
\hline 3 & Alanine & 6121.63 & 8162.17 & $\mathrm{ppm}$ \\
\hline 4 & Glycine & 5327.34 & 7103.12 & $\mathrm{ppm}$ \\
\hline 5 & Serine & 4724.26 & 6299.01 & $\mathrm{ppm}$ \\
\hline 6 & Proline & 3569.25 & 4759.00 & $\mathrm{ppm}$ \\
\hline 7 & Tyrosine & 2720.49 & 3627.32 & $\mathrm{ppm}$ \\
\hline 8 & Cysteine & 127.59 & 170.12 & $\mathrm{ppm}$ \\
\hline & & & \\
\hline
\end{tabular}

Table 2: Content of amino acids of Chlorella vulgaris and fusant.

\begin{tabular}{|c|c|c|c|}
\hline S. no & Lipid acid & $\begin{array}{c}\text { C. vulgaris } \\
\text { (\%) }\end{array}$ & $\begin{array}{c}\text { Fusant } \\
(\%)\end{array}$ \\
\hline 1. & C 4:0 (Butyric acid) & 0.0120 & 0.0147 \\
\hline 2. & C 6:0 (Caproic acid) & 0.0020 & $<0.0013$ \\
\hline 3. & C 8:0 (Caprylic acid) & 0.0200 & 0.0267 \\
\hline 4. & C 10:0 (Capric acid) & 0.0264 & 0.0339 \\
\hline 5. & C 11:0 (Undecanoic acid) & 0.0014 & $<0.0016$ \\
\hline 6. & C 12:0 (Lauric acid) & 0.1496 & 0.1988 \\
\hline 7. & C 13:0 (Tridecanoic acid) & 0.0657 & 0.0862 \\
\hline 8. & C 14:0 (Myristic acid) SFA & 0.3981 & 0.5295 \\
\hline 9. & C 14:1 (Myristoleic acid) & $<0.0014$ & $<0.0017$ \\
\hline 10. & C 15:0 (Pentadecanoic acid) SFA & 0.0258 & 0.033 \\
\hline 11. & C 15:1 (Pentadecenoic acid) & $<0.0013$ & $<0.0016$ \\
\hline 12. & C 16:0 (Palmitic acid) SFA & 1.19730 & 1.5964 \\
\hline 13. & C 16:1 (Palmitoleic acid) MUFA & 1.05985 & 1.4131 \\
\hline 14. & C 17:0 (Heptadecanoic acid) & 0.0239 & 0.0317 \\
\hline 15. & C 17:1 (Heptadecenoic acid) & $<0.0015$ & $<0.0016$ \\
\hline 16. & C 18:0 (Stearic acid) SFA & 0.1298 & 0.1729 \\
\hline 17. & C 18:1 (Oleic acid) MUFA & 0.41239 & 0.5505 \\
\hline 18. & C 18:2 (Linoleic acid)PUFA & 0.1040 & 0.1387 \\
\hline 19. & C 18:3 (Linolenic acid)PUFA & $<0.0012$ & $<0.0015$ \\
\hline 20. & C 18:3 (Linolenic acid/ALA)PUFA & 0.0246 & 0.0315 \\
\hline 21. & C 20:0 (Arachidic acid) SFA & 0.0186 & 0.0234 \\
\hline 22. & C 20:1 (Eicosenoic acid) & $<0.0012$ & $<0.0015$ \\
\hline 23. & C 20:2 (Eicosedienoic acid) & $<0.0013$ & $<0.0015$ \\
\hline 24. & C 20:3 W3(Eicosatrienoic acid) & $<0.0012$ & $<0.0016$ \\
\hline 25. & C 20:3 W6(Eicosatrienoic acid ) & $<0.0015$ & $<0.0016$ \\
\hline 26. & C 20:4 W6 (Arachidonic acid/AA) & 0.1508 & 0.2010 \\
\hline 27. & C 20:5 W3(Eicosapentaenoic acid/EPA)Omega 3 & 0.8250 & 1.0987 \\
\hline 28. & C $21: 0$ (Heneicosanoic acid) & 0.0179 & 0.0236 \\
\hline 29 & C 22:0 (Behenic acid) & $<0.0014$ & $<0.0014$ \\
\hline 30. & C 22:1 (Erucic acid) & $<0.0011$ & $<0.0015$ \\
\hline 31. & C 22:2 (Dokosadienoic acid) & $<0.0012$ & $<0.0016$ \\
\hline 32. & C 22:6 (Docosahexaenoic acid/DHA) & $<0.0019$ & $<0.0023$ \\
\hline 33. & C 23:0 (Tricosanoic acid) & $<0.0012$ & $<0.0014$ \\
\hline 34. & C 24:0 (Lignokeric acid) & $<0.0012$ & $<0.0016$ \\
\hline 35 & Omega 3 & $<0.9475$ & $<1.25$ \\
\hline 36 & Omega 3 total & 0.8240 & 1.0987 \\
\hline 37 & Omega 6 & 0.1050 & 0.1387 \\
\hline 38 & Omega 6 total & 0.2785 & 0.3713 \\
\hline 39 & Omega 9 & 0.4139 & 0.5505 \\
\hline 40 & Omega 9 total & 0.4129 & 0.5505 \\
\hline 41 & Unsaturated fatty acid & 2.59520 & 3.4336 \\
\hline 42 & Saturated fatty acid & 2.07883 & 2.7715 \\
\hline 43 & Monounsaturated fatty acid (MUFA) & 1.48270 & 1.9636 \\
\hline 44 & Total Polyunsaturated fatty acid (PUFA) & 1.10443 & 1.4699 \\
\hline 45 & AA & 0.1508 & 0.2010 \\
\hline 46 & DHA & $<0.0009$ & $<0.0012$ \\
\hline 47 & PUFA & 0.8240 & 1.0987 \\
\hline
\end{tabular}

AA: Arachidonic Acid; DHA: Docosahexaenoic Acid; SFA: Saturated Fatty Acid; MUFA: Monounsaturated Fatty Acid; PUFA: Polyunsaturated Fatty Acid

Table 3: Fatty acid acid profile of Chlorella vulgaris and fusant.

contrast with Brown et al. [37], also Guedes and Malcata [19] which is stated that Chlorella spp. as a Chlorophytes are deficient in both C20 and C22 PUFAs. Moreover, C. vulgaris and fusant demonstrated high concentrations of Omega 3, as well as a a low concentration of Omega 6. Surprisingly, we also found moderate concentration of Omega 9. This result was different with Sayeda et al. [13] which was not detected omega 9 in C. vulgaris. Among all the fatty acids in microalgae, Omega 3 and Omega 6 families are of particular interest. In addition, highly unsaturated fatty acid (e.g., eicosapentanoic acid (EPA), arachidonic 


\begin{tabular}{|c|c|c|c|c|c|}
\hline Variables & Compound name & C.vulgaris (\% area) & RT & Fusant (\% area) & RT \\
\hline \multirow{3}{*}{ Omega 6} & Hexadecenoic acid, 2-hydroxy-1,3-propanediyl ester (CAS) & 8.60 & 48.021 & $13.61 ; 4.41$ & 48.01052 .115 \\
\hline & Hexadecenoic acid, methyl ester (CAS) & 1.97 & 39.982 & & \\
\hline & 9,12-Octadecadienoic acid (Z, Z)-, 2-hydroxy-1-(hydroxymethyl)ethyl ester (CAS) & 30.62 & 51.384 & 26.47 & 51.381 \\
\hline \multirow{4}{*}{ Omega 9} & 9-Octadecenoic acid (Z)-, 2,3-dihydroxypropyl ester (CAS) & -- & -- & 55.43 & 51.576 \\
\hline & 9-Octadecenoic acid (Z)-, 2-(acetyloxy)-1- [(acetyloxy)methyl] ethyl ester (CAS) & 46.62 & 51.562 & -- & -- \\
\hline & 9-Octadecenoic acid (Z)-, methyl ester (CAS) & 2.39 & 43.989 & -- & -- \\
\hline & 14-BETA-H-PREGNA & 3.35 & 51.680 & -- & -- \\
\hline
\end{tabular}

Table 4: GC/MS chemical profile of $C$. vulgaris and fusant omega fatty acids ester.

acid (AA) and docosahexaenoic acid (DHA) also found in C. vulgaris and fusant. Because of its role as a producer in the food chain at sea, microalgae also potentially being a source of polyunsaturated fatty acids (PUFA), $\delta$-linoleic acid (GLA). The total amount and relative proportion of fatty acids can be affected by nutritional and environmental factors, nitrogen limitation. We also found C16:0, C16:1, C18:1 C18:2 and C18:3 which have not been reported before for $C$. vulgaris (Table 3 ). The existence of the erucic acid methyl ester (C22:0), arachidic acid methyl ester (C20:0), palmitic acid methyl ester (C16:0), cis-11-eicosenoic methyl ester (C20:1), cis-11, 14-eicosadienoic acid methyl ester (C20:2) and linolenic acid methyl ester (C18:3) might be potencial as antimicrobial agent based on the experiment conducted by Suresh et al. [11]. The fatty acid composition of green alga Chlorella of 14:0, 16:0,16:1, 16:2,16:3, 18:0, 18:1, 18:2, 18:3 is confirmed under all kinds of cultivation conditions as those mentioned by Wang et al. [7].

Our research as exhibited in Table 4. also showed the natural occurrence of Fatty acid ester in C. vulgaris and fusant. Major fatty acid esters were C16:0 and C18:1 (Table 3), in agreement with a previous work on $C$. reinhardtii. The hexadecanoic acid also dominant for macroalgae, Himanthalia elongata [9]. Octadecadienoic acid was the most abundant fatty acid under laboratory conditions for both C. vulgaris and fusant. Hexadecanoic acid was the second abundant fatty acid. Both acids increased in their contents in the fusant. It is also found that the fusant also tend to have the same retention time with their parental for similar compound of fatty acid. Surprisingly, fusant and their parental C. vulgaris producing different type of Omega 9 compound in almost the same time retention.

Based on the research, it is showed that protoplast fusion process could be enhanced all of the nutritional value af $C$. vulgaris. This process also could create a new compound that can be found in their parental like 14-BETA-H-PREGNA fatty acid. The nutritional value of fusant from C. vulgaris not only exhibited a similar trend with their parental but also tend to increase and vary more nutritional compound.

\section{Conclusion}

Protoplast fusion are a method for improving nutrition which show great promise, but have yet to be investigated sufficiently in microalgae. In this work, application of protoplast fusion process and their effect on the nutritional value in C. vulgaris is presented. This tehcniques not only allows to increased the original compounds found and also vary the nutritional compound. It can be considered as a powerful tool in microalgae. The possibility to find functional interesting compounds from microalgae using this techniques looks promising.

\section{Acknowledgment}

The authors gratefully thank to Directorate of Research and Public Services (Dirlitabmas), Indonesian Ministry of Research, technology and Higher Education according to Letter of Assigment of Hibah PUPT, Number: 344-43/UN7.5.1/PP/2017 date 5 May 2017 in funding this research.

\section{References}

1. Kusumaningrum HP Zainuri $M$ (2015) Detection of bacteria and fung associated with Penaeus monodon postlarvae mortality. Procedia Environ Sci pp: 329-337.

2. Pulz O, Gross W (2004) Valuable products from biotechnology of microalgae Appl Microbiol Biotechnol 65: 635-648.

3. Lee YK, Tan HM (1988) Interphylum protoplast fusion and genetic recombination of the algae Porphyridium cruentum and Dunaliella spp. J Gen Microbiol 134 $635-641$.

4. Kusumaningrum HP, Zainuri M (2014) Optimization and stability of tota pigments production of fusan from protoplast fusion of microalgae Dunaliella and Chlorella in vivo: Attempts on production of sustainable aquaculture natura food. Int J Marin Aqua Res Conserv Co-exist 1: 1-5.

5. Santiago CM (1982) Protoplast fusion a new technique for genetic manipulation and breeding of industrial microorganisms. IC Biotech 5: 435-440.

6. Lu Y, Kong R, Hu L (2012) Preparation of protoplasts from Chlorella protothecoides. World J Microbiol Biotechnol 28: 1827-1830.

7. Wang L, Li Y, Chen P, Min M, Chen Y, et al. (2010) Anaerobic digested dairy manure as a nutrient supplement for cultivation of oil-rich green microalgae Chlorella sp. Biores Technol 101: 2623-2628.

8. Herrera-Valencia VA, Us-Vázquez RA, Larqué-Saavedra FA, Barahona-Pérez LF (2012) Naturally occurring fatty acid methyl esters and ethyl esters in the green microalga Chlamydomonas reinhardtii. Ann Microbiol 62: 865-870.

9. Plaza M, Santoyo S, Jaime L, Reina GG, Herrero M, et al. (2010) Screening for bioactive compounds from algae. J Pharma Biomed Anal 51: 450-455.

10. Kusumaningrum HP, Zainuri M (2013) The natural wealthy carotenoid feed application for post larvae Penaeus monodon Fab. I J IImu Kelautan 18: 143-149.

11. Suresh A, Rasamamy P, Felix T, Oscar L, Baldev E, et al. (2014) Microalgal fatty acid methyl ester a new source of bioactive compounds with antimicrobial activity. Asia Pacific J Tropic Dis 4: 979-984.

12. Kent M, Welladsen HM, Mangott A, Li Y (2015) Nutritional evaluation of australian microalgae as potential human health supplements. Plos One 27: 1-14.

13. Sayeda MA, Ali GH, El-Baz FK (2015) Potential production of omega fatty acids from microalgae. Int J Pharm Sci Rev Res 34: 210-215.

14. Soltani N, Latifi AM, Alnajar N, Dezfulian M, Shokarvi S, et al. (2016) Biochemical and physiological characterization of tree Microalgae spp. as candidates for food supplement. J Appl Biotechnol Rep 3: 377-381.

15. Bleakley S, Hayes M (2017) Algal proteins: Extraction, application, and challenges concerning production. Rev Food 6: 33

16. Handayania NA, Ariyantib D, Hadiyanto P (2012) Potential production of polyunsaturated fatty acids from microalgae. Sci Rep 1: 180.

17. Panaiotov S, Evstatieva Y, llieva S (2009) Quantitative assesment of the dominant genome in fusant cultures. Biotechnol Equip 23: 892-895.

18. Guedes AC, Amaro HM, Malcata FX (2011) Microalgae as sources of carotenoids. Marine Drug 9: 625-644.

19. Guedes AC, Malcata FX (2012) Nutritional value and uses of microalgae in aquaculture. Agri Bio Sci.

20. Boonyaratpalin M, Thongrod S, Supamattaya K, Britton G, Schlipalius LE (2001) Effects of $\beta$-carotene Source, Dunaliella salina, and Astaxanthin on pigmentation, growth, survival and health of Penaeus monodon. Aqua Res 32 182-190. 
Citation: Kusumaningrum HP, Zainuri M (2018) Improvement of Nutrition Production by Protoplast Fusion Techniques in Chlorella vulgaris. J Food Process Technol 9: 711. doi: 10.4172/2157-7110.1000711

Page 5 of 5

21. McVey JP, Moore JR (1983) Algal food cultures at the centre oceanologique du pacifique. Crustacean Aquaculture, CRC Press, Boca Raton, USA.

22. Bidwell JP, Spotte S (1985) Artificial sea water: Formulas and methods. Artificial sea water, Boston, Massachusetts, USA

23. AOAC (1995) Official methods of analysis of the association of official analytica chemists (16th edn.). AOAC, Washington DC.

24. Tjahjono AE, Kakizono T, Hayama Y, Nishio N, Nagai S (1994) Isolation of resistant mutants against carotenoid biosynthesis inhibitors for a green alga Haematococcus pluvialis, and their hybrid formation by protoplast fusion for breeding of higher astaxanthin producer. J Ferment Bioeng 77: 352-357.

25. Uppalapati SR, Fujita Y (2002) A simple method for mass isolation of protoplasts from species of Monostroma, Enteromorpha and Ulva (Chlorophyta, Ulvales). J Appl Phycology 14: 165-168.

26. Chia MA, Lombardi AT, Melão MG (2013) Growth and biochemical composition of Chlorella vulgaris in different growth media. Annal Brazil Acad Sci 85: 1427-1438

27. Costard GS, Machado RR, Barbarino E, Martino RC, Lourenço SO (2012) Chemical composition of five marine microalgae that occur on the Brazilian coast. Int J Fish Aqua 4: 191-201.

28. Kusumaningrum HP, Zainuri M (2016) Molecular characterization of Dunaliella salina and Chlorella vulgaris fusant using 18SrDNA gene. Jurnal Teknologi 78: $61-68$

29. Gupta DV, Kumari P, Reddy CK (2015) Development and characterization of somatic hybrids of Ulva reticulata Forsskål $(x)$ Monostroma oxyspermum
(Kutz.). Frontier Plant Sci Plant Evol Develop 6: 1-15

30. Sharma R, Singh GP, Sharma VK (2012) Effects of culture conditions on growth and biochemical profile of Chlorella vulgaris. J Plant Pathol Microb 3: 5.

31. Bi Z, He BB (2013) Characterization of microalgae for the purpose of biofue production. America Soc Agri Biol Eng 56: 1529-1539.

32. Yusof YM, Basari JH, Mukti NA, Sabuddin R, Muda AR, et al. (2011) Fatty acids composition of microalgae Chlorella vulgaris can be modulated by varying carbon dioxide concentration in outdoor culture. Africa J Biotechnol 10: 13536-13542.

33. Torres LG, Corzo LG, Mimouni V, Ulman L (2017) Proximate analysis, lipid profile microbiological and pigment characterization of Chlorella dry powder produced in a $20 \mathrm{~L}$ agitated photobioreactor. Asia J Biotechnol Biores Technol 2: 1-10.

34. Samek D, Mišurcová L, Machů L, Buňka F, Fišera M (2013) Influencing of amino acid composition of green freshwater algae and cyanobacterium by methods of cultivation. Turkish J Biochem 38: 360-368.

35. Safafar H, Nørregaard PU, Ljubic MA, Holdt SL, Charlotte J (2016) Enhancement of protein and pigment content in two chlorella species cultivated on industrial process water. J Mar Sci Eng 4: 1-15.

36. Volkmann H, Imianovsky U, Oliveira JB, Sant'Anna ES (2008) Cultivation of Arthrospira (Spirulina) platensis in desalinator waste water and salinated synthetic medium: Protein content and amino-acid profile Braz J Microbiol 39 98-101.

37. Brown MR, Jeffrey SW, Volkman JK, Dunstan GA (1997) Nutritional properties of microalgae for mariculture. Aquacultur 151: 315-331. 